Available online on 15.11.2020 at http://ujpr.org
Universal Journal of Pharmaceutical Research
An International Peer Reviewed Journal
Open access to Pharmaceutical research

\title{
STUDY LITERATION OF CHEMICAL CONTENTS OF SOME PLANTS THAT POTENTIALLY AS THE SOLAR SOWS Sukmawati* ${ }^{*}$, Dwi Rizka Sari Kaswan 1 , Mamat Pratama \\ Faculty of Pharmacy,Universitas Muslim Indonesia, Makassar, Indonesia.
}

\section{ABSTRACT}

Excessive sun exposure causes the epidermal tissue of the skin to be unable to fight negative effects such as skin disorders ranging from mild dermatitis to skin cancer, so skin protection is needed such as the use of sunscreen, many plants in Indonesia contain phenolic and flavonoid contents that can potentially act as sunscreens. This study aims to determine the chemical content of several plants that have potential as sunscreen. Where this research was conducted through data collection from several scientific research journals. The data collection is done online using Google, Google Scholar. Based on the data obtained from several scientific research journals, it can be stated that some plants have the potential to act as sunscreens, by looking at the content they have, namely phenolic and flavonoids. The ethanol extract of $96 \%$ of Sembung Rambat Plants (Mikania micrantha Kunth) with an SPF value of 42.8810 with a total flavanoid content of $1.175 \%$.

Keywords: Chemical content, literacy studies, sunscreen, Sun Protection Factor (SPF).

Article Info: Received 23 August 2020; Revised 26 September; Accepted 4 November, Available online 15 November 2020

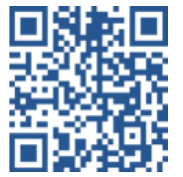

\section{Cite this article-}

Sukmawati, Kaswan DRS, Pratama M. Study literation of chemical contents of some plants that potentially as the solar sows. Universal Journal of Pharmaceutical Research 2020; 5(5):92-94.

DOI: https://doi.org/10.22270/ujpr.v5i5.493

Address for Correspondence

Sukmawati, Faculty of Pharmacy, Universitas Muslim Indonesia, Makassar, Indonesia, Tel: 081350558806; E-mail: sukmawati.syarif@umi.ac.id

\section{INTRODUCTION}

The sun is a source of life for mankind and the earth not always had an impact that profitable because it could create a loss in human skin.Ultraviolet light contained in the sun may hurt the skin. When exposure of the sun is redundant it will cause harmful effects ${ }^{1}$. Sunlight considered a major factor of various skin problems, ranging from sunburn, skin pigmentation, skin aging, furthermore skin cancer.Leather radiated UV ray will appear darker, wrinkled, dull, dry , arising blackish brown spots, until skin cancer ${ }^{2}$. The Preparation of ingredients of nature hasconsidered more safe to use and another negative effectwhich affected fewer more than the use of chemical. Supported by Indonesian natural wealth, the cosmetics industry can use fitoconstituen from diverse plants for an antidote UV light ${ }^{3}$. Sunscreen preparations are recommended to be used to prevent or minimize the harmful effects of UV rays on the skin. The bad effect of UV rays on the skin is usually can usuallycan be minimized by the use of materials that are UV protective. The bad effects of UV rays on the skin usually cause damage to the skin which can affect one's health and appearance ${ }^{4}$. Sunscreen content is a substance that contains skin protective ingredients against sunlight so that UV rays cannot enter the skin (preventing skin irritation due to radiation). Sunscreen can protect the skin by spreading sunlight or absorbing solar radiation energy that hits the skin, so that the radiation energy does not directly hit the skin ${ }^{5}$. Phenolic contents, especially the flavanoid group, have potential as sunscreens because of the presence of chromophore groups (conjugated single double bonds) which can absorb both UVA and UVB rays. Flavonoids show a strong absorption band in the ultraviolet light spectrum and visible light spectrum ${ }^{7}$. Based on this, researchers are interested in conducting literature review, which about the chemical content of several plants that have the potential as sunscreen ${ }^{1}$.

\section{METHODS}

Literature review is a method used to collect data or sources related to a particular topic that can be obtained from various sources such as journals, books, the internet and other literature. These libraries are downloaded from several databases such as Science Direct, Pubmed, and Google Scholar. The keywords 
used in the search for information were "total phenolic and flavanoid contents and sunscreen activity"2.

\section{Inclusion criteria}

The inclusion criteria of this study include search results on Google Scholar and PubMed with the keywords "total content and sunscreen activity", the researchers found 15,900 journals that match these keywords. After being selected based on a maximum journal publication period of 10 years (2010-2020), Indonesian and English language journals, original research, national journals, up to 5 journal titles.

\section{Exclusion criteria}

Based on search results on Google Scholar and PubMed with the keywords "total phenolic contents and flavonoids, and sunscreen", researchers found 15,900 journals that match these keywords. 7,260 journals were selected and excluded because the time span was below 2010. Then they were screened, 578 journals were excluded because full text articles were not available. Feasibility assessment of 250 full text journals was carried out, journals that were duplicated and did not meet the inclusion criteria were excluded as many as 230 journal titles. Selection of journals based on: extraction method, $96 \%$ solvent, total phenolic and flavanoid contents, and sunscreen activity.

\section{DISCUSSION}

Sunscreen is a cosmetic preparation that is used with the intention of reflecting or absorbing UV rays so as to reduce the amount of UV radiation that is harmful to the skin $^{1}$. Sunscreen content against sunlight so that UV rays cannot enter the skin (preventing skin irritation due to radiation). Sunscreen can protect the skin by spreading sunlight or absorbing solar radiation energy that hits the skin, so that the radiation energy does not directly hit the skin ${ }^{9}$. Based on its working mechanism, the active ingredients of sunscreens are acting by one of physical blocking mechanism (reflecting solar radiation) and the chemical absorbing mechanism (absorbing solar radiation) ${ }^{3}$. Physical sunscreens work by reflecting ultraviolet radiation, their ability to block UV rays from penetrating the deepest layers of the skin, namely the dermis tissue and even to the hypodermis by blocking or reflecting and dissipating UV light energy, and is effective in the UVA and UV-B radiation spectrum, while chemical sunscreens, they mechanism of actionabsorbs ultraviolet radiation by absorbing solar energy radiation before it reaches the skin, can absorb nearly 95\% of UV-B radiation which can cause sunburn (burns) ${ }^{10}$. Flavonoids have potential as sunscreens because of the presence of chromophore groups that generally give plants their color ${ }^{4}$. The chromophore group is a conjugated aromatic system that causes the ability to absorb light strongly in the UV light wave length range ${ }^{5}$, the largest group of phenolic contents are flavonoids. According to a previous research ${ }^{12}$ using a sample of avocado seeds (Persea americana Mill.) by using the maceration method and using $96 \%$ ethanol solvent, based on this research, the total phenolic conten of avocado seeds (Persea americana mill.) was obtained, namely $6,41 \mathrm{mg}$ and the total flavanoid content of avocado seed (Persea americana Mill. as $1.90 \mathrm{mg}$, based on the research results obtained the SPF value of ethanol extract of avocado seeds (Persea americana Mill) as the highest SPF value at concentrations of $1000 \mathrm{ppm}$ with an SPF value of 8.02 which belongs to the maximum protection category. According to a previous study samples of corn cobs and hair (Zea mays L.) using the maceration method and using $96 \%$ ethanol solvent, based on this research, the total results of phenolic content from corn cobs extract (Zea mays L.) was $20.886 \mathrm{mg} / \mathrm{G}$ and the total phenolic content from corn hair extract (Zea mays L.). was $26.060 \mathrm{mg} / \mathrm{G}$, then the Sun Protection Factor value is 7.985 and the SPF value of maize hair extract was 20,784 (Zea mays L.) ${ }^{14,15}$.

Table 1: The results of a literature study on the chemical content of several plants that have potential as sunscreens.

\begin{tabular}{|c|c|c|c|c|c|}
\hline Sample & Solvent & $\begin{array}{l}\text { Extraction } \\
\text { method }\end{array}$ & Total compound & $\begin{array}{c}\text { SPF } \\
\text { value }\end{array}$ & Sources \\
\hline $\begin{array}{l}\text { Avocado seeds } \\
\text { (Persea } \\
\text { americana } \\
\text { Mill.) }\end{array}$ & $\begin{array}{l}\text { Ethanol } \\
96 \%\end{array}$ & Maceration & $\begin{array}{l}\text { Phenolic : } 6.41 \mathrm{mg} \\
\text { Flavanoid : } 1.90 \mathrm{mg}\end{array}$ & 8.02 & $\begin{array}{l}\text { Suhaenah, A, Widiastuti, H, \& Arafat, M } \\
2019 \text {, 'The Potential of Avocado Seed } \\
\text { (Persea americana Mill.) Ethanol Extract as } \\
\text { Sunscreen }\end{array}$ \\
\hline $\begin{array}{l}\text { Corn cobs and } \\
\text { hair (Zea mays } \\
\text { L.) }\end{array}$ & $\begin{array}{l}\text { Ethanol } \\
96 \%\end{array}$ & Maceration & $\begin{array}{l}\text { Corn cobs extract } \\
\text { Phenolic : } 20.886 \mathrm{mg} / \mathrm{G} \\
\text { Corn hair extract } \\
\text { Fenolik : } 26.060 \mathrm{mg} / \mathrm{G}\end{array}$ & 20.784 & $\begin{array}{l}\text { Kusriani, H, Marliani, L, \& Apriliani E 2017, } \\
\text { 'Antioxidant and Sunscreen Activity of Corn } \\
\text { Cob and Hair (Zea mays L.). }\end{array}$ \\
\hline $\begin{array}{l}\text { Sembung vine } \\
\text { plants (Mikania } \\
\text { micrantha } \\
\text { Kunth) }\end{array}$ & $\begin{array}{l}\text { Ethanol } \\
96 \%\end{array}$ & Maceration & Flavanoid : $1.175 \%$ & 42.8810 & $\begin{array}{l}\text { Susanti, E, \& Lestari, S 2019, 'Sunscreen } \\
\text { Activity Test of In Vitro Ethanol Extract of } \\
\text { Sembung Plants (Mikania micrantha Kunth). }\end{array}$ \\
\hline $\begin{array}{l}\text { Marpuyan } \\
\text { leaves } \\
\text { (Rhodamnia } \\
\text { cinerea Jack.) } \\
\end{array}$ & $\begin{array}{l}\text { Ethanol } \\
96 \%\end{array}$ & Maceration & $\begin{array}{l}\text { Flavanoid : } 0.1033 \\
\mu \mathrm{g} / \mathrm{mg} \\
\text { Phenolic : } 0.0983 \\
\mu \mathrm{g} / \mathrm{mg}\end{array}$ & 20.7 & $\begin{array}{l}\text { Nasution, MR, dkk. 2020, 'Determination of } \\
\text { Sunscreen Activity Ethanol Extract of } \\
\text { Marpuyan Leaves (Rhodamnia cinerea Jack.) } \\
\text { by In Vitro '. }\end{array}$ \\
\hline $\begin{array}{l}\text { Black Rice } \\
\text { (Oryza Sativa L. } \\
\text { Indica) }\end{array}$ & $\begin{array}{l}\text { Ethanol } \\
96 \%\end{array}$ & Maceration & $\begin{array}{l}\text { Flavanoid : } 37.75 \pm \\
0.23 \mathrm{mg}\end{array}$ & 10.37 & $\begin{array}{l}\text { Fanani, Z, Masithoh, RA, \& Wariana KM } \\
\text { 2019, 'Analysis of Sunscreen Potential of } \\
\text { Black Rice (Oryza Sativa L. Indica)'. }\end{array}$ \\
\hline
\end{tabular}


According to a previous study using a sample of sembung vine (Mikania micrantha Kunth) using the maceration method and using ethanol solvent, based on this research, the total results of the flavonoid content of the sembung creeper (Mikania micrantha Kunth) was $1.175 \%$ and the calculation of the value Sun Protection Factor using a concentration of $250 \mathrm{ppm}$ has a good sunscreen activity with a percent value of erythema transmission, a percent value of pigmentation transmission in the sunblock category and an SPF value of 42.8810 with a high protection category ${ }^{12}$. According to based on research conducted using marpuyan leaf plants (Rhodamnia cinerea Jack.) Using maceration methods and ethanol solvents, while the total marpuyan leaf flavanoid content (Rhodamnia cinerea Jack.) wer.1033 $\mu \mathrm{g} / \mathrm{mg}$ and phenolic 0.0983 $\mu \mathrm{g} / \mathrm{mg}$. From this research, the calculation of the value of the Sun Protection Factor showed that the ethanol extract of marpuyan leaves (Rhodamnia cinerea Jack.) had a strong sunscreen activity on a test concentration of $1000 \mathrm{~g} / \mathrm{mL}$ with an SPF value of 20.7. Fanani, Z, Masithoh, RA, and Wariana KM (2019), ased on research conducted using black rice plants (Oryza Sativa L. Indica) using maceration methods and $96 \%$ ethanol solvent, as for the total black rice flavanoid content (Oryza Sativa L. Indica), was $7.75 \pm 0.23 \mathrm{mg}$. From this research, the calculation of the value of the Sun Protection Factor was carried out. The results showed that the ethanol extract of black rice (Oryza Sativa L. Indica) had sunscreen activity with maximum protection obtained at a concentration of 500ppm with an SPF value of 10.37. Based on the results bove, it can be concluded that some plants contain phenolic and flavanoid contents which can be potential as sunscreens ${ }^{15}$. From several journals with different plants, it showed the highest SPF value, namely the ethanol extract of $96 \%$ of Sembung Rambat Plants (Mikania micrantha Kunth) with an SPF value of 42.8810 with a total flavanoid content of $1.175 \%$. The phenolic contents found in plants serve to protect plant tissues against damage caused by solar radiation. Phenolic contents, especially the flavonoid group, have potential as sunscreens because of the presence of chromophore groups that can absorb UV rays, thereby reducing their intensity on the $\operatorname{skin}^{12}$.

\section{CONCLUSION}

Based on several research journals on the chemical content of several plants that have potential as sunscreens, some plants contain phenolic and flavanoid contents. So it can be concluded that some plants can be potential as sunscreens by looking at the presence of phenolic contents and flavonoids contained. The highest Sun Protection Factor value was in the ethanol extract of $96 \%$ of the Sembung Rambat Plant (Mikania micranthaunth) using the maceration extraction method with an SPF value of 42.8810 with a total flavanoid Content f $1.175 \%$.

\section{ACKNOWLEDGEMENTS}

The researchers would like to thank for the fund assitance from Faculty Of Pharmacy at Universitas Muslim Indonesia, Makassar, Indonesia.

\section{REFERENCES}

1. Cefali LC, Ataide JA, Fernandes AR, et al. Evaluation of in vitro solar protection factor (Spf), antioxidant activity, and cell viability of mixed vegetable extracts from Dirmophandra mollis benth, Ginkgo biloba L., Ruta graveolens L., and Vitis vinífera L. Plants 2019; 8(11):1-13. https://doi.org/10.3390/plants8110453

2. Almuqati RR, Alamri AS, Almuqati NR. Knowledge, attitude, and practices toward sun exposure and use of sun protection among non-medical, female, university students in Saudi Arabia: A cross-sectional study. Int J Women's Dermatol 2019; 5(2):105-109. https://doi.org/10.1016/j.ijwd.2018.11.005

3. Sultana N. Sun awareness and sun protection practices. Clin Cosmet Investig Dermatol 2020; 13:717-730. https://doi.org/10.2147/CCID.S265477

4. Hernández AR, Vallejo B, Ruzgas T, Bjorklund S. The effect of UVB irradiation and oxidative stress on the skin barrier A new method to evaluate Sun. Sensors 2019; 19(10):2376. https://doi.org/10.3390/s19102376

5. Fanani Z, Masithoh RA, Wariana KM. Analysis of the Potential of Sunscreen from Black Rice (Oryza Sativa L. Indica)', Urecol (University Research Colloquium). Institute of Health Science Muhammadiyah Gombong 2019; 473-477.

6. Nasution MR, Sari ARP, Utami IP, Halianti T. Determination of sunscreen activity of ethanol extract Marpuyan (Rhodamnia cinerea Jack.) with in vitro. J Dunia Farm Institute Pharm Sci Riau 2020; 4(2): 59-67.

7. Sami JF, Nur S, Martani MM. Sunscreen activity test on several species of the Zingiberaceae family using the spectrophotometric method. As-Syifaa 2005; 07(2): 164-173.

8. Pratama WA, Zulkarnain AK. In vitro SPF test for physical properties of some sunscreen products on the market, Majalah Farmaseutik. Pharmacy of Faculty UGM Yogyakarta 2015; 11(1):275-283.

9. Putri YD, Kartamihardja H, Lisna I. Formulasi dan Evaluasi Losion Tabir Surya Ekstrak Daun Stevia (Stevia rebaudiana Bortoni M). J Sains Farmas Klinis 2019; 6(1): 32-36.

10. Manik AES, Melati M, Kurniawati A, Faridah DN. Hasil dan Kualitas Okra (Abelmoschus esculentus (L.) Moench.) Merah dan Okra Hijau dengan Jenis Pupuk yang Berbeda. J Agron. Indonesia 2019; 47((1):68-75.

11. Kusriani H, Marliani L, Apriliani E. Aktivitas Antioksidan dan Tabir Surya dari Tongkol dan rambut Jagung (Zea mays L.). IIndonesian J Pharm Sci Tech 2017; 4(1):10-17.

12. Laeliocattelya RA, Prasiddha IJ, Estiasih T, et al. Potensi Senyawa Bioaktif Rambut Jagung (Zea mays L.) Hasil Fraksinasi Bertingkat Menggunakan Pelarut Organik Untuk Tabir Surya Alami', J Teknologi Pertanian Fakultas Teknologi Pertanian, Universitas Brawijaya Malang, 2014; 15(3):175-84.

13. Pratiwi S, Husni P. Artikel Tinjauan : Potensi Penggunaan Fitokonstituen Tanaman Indonesia sebagai Bahan Aktif Tabir Surya. Farmaka, Fakultas Farmasi Universitas Padjadjaran 2017; 15(4):18-25.

14. Lavi N 2012, Sunscreen For Travellers, Denpasar, Departement Pharmacy Faculty of Medicine, University of Udayana 2012; 6 .

15. Sukmawati, Amirah S, Sardini J, Handayani H. Antiinflammatory potential of extract of Nothopanax fruticosum (L.) Miq by method of erythrocyte membrane stability. Int $\mathbf{J}$ Med Sci Dental Res 2020;3(03). https://doi.org/10.13140/RG.2.2.14264.37126

16. Suhaenah A, Widiastuti H, Arafat M. Potensi Ekstrak Etanol Biji Alpukat (Persea americana Mill.) sebagai Tabir Surya', ad-Dawaa. J Pharm Sci 2019; 2(2):88-94. 